\title{
A development of career guidance modules to improve youth career planning: Study at the Parupuk Tabing youth family development, Koto Tangah, Padang, West Sumatra
}

\author{
Agung Satria Wijaya ${ }^{1(*)}$, A. Muri Yusuf ${ }^{1}$, Agus Irianto $^{2}$ \\ ${ }^{1}$ Dep. of Guidance and Counseling, Faculty of Education, Universitas Negeri Padang, Padang, Indonesia \\ ${ }^{2}$ Dep. of Economic Education, Faculty of Economy, Universitas Negeri Padang, Padang, Indonesia \\ "Corresponding author. Email: agungsatriawijaya533@gmail.com
}

\begin{abstract}
One of the development tasks that must be achieved by adolescents is planning for a future career. Career planning is an important part that will determine the success of adolescents. The purpose of this study is to describe adolescent career planning for doing coaching at the program named Bina Keluarga Remaja (BKR) arranged by coaches and counselors. The method that used in this study was part of the development of the ADDIE model. The arrangement of the test involved three experts and the implementation was assisted by the BKR coach and counselor. The instrument usedin attitude questions formusing a Likert Scale Model. The data analysis was performed with the description and results of the analysis showed that the level of adolescent career planning was at a moderate level and tended to be low. Based on the five aspects of career planning measured, aspects of attitudes towards work are at a low condition. Whereas the four remaining aspects are in a low tendency with the lowest order there are action plans, self-understanding, understanding of the world of work, and formulating choices. The level of material suitability is in the very feasible category. For this reason, it is necessary to develop a career guidance module that can be used by adolescents in career planning.
\end{abstract}

\section{Keywords: Career planning, bina keluarga remaja (BKR), module}

\section{INTRODUCTION}

The transition period experienced by humans between the ages of children with adulthood is called adolescence. Someone can be said to be a teenager if he has reached the age of 11 or 12 years. Adolescence is a determinant of one's success in the future, if adolescents are able to complete their developmental tasks. One of the tasks of this development is to achieve economic independence beginning with understanding yourself and the career/work environment (Atmaja, 2014; Istriyanti \& Simarmata, 2014). Career is a life process that a person goes through, starting with studying, continuing with work, and ending with entering retirement.

Teenagers at the career development stage should be educated or working. Adolescents (15-24 years) in accordance with this stage are in the career exploration section marked by youth activities to search for, obtain, and manage career information (Priyatno, 2016). Career exploration aims to make teenagers able to search for careers in the environment in accordance with the characteristics of their careers, so they can choose a career independently.
Choosing and determining a career is not easy for teens. Teenagers are still hesitant to answer questions related to where I am next? What do I think about the job / career that suits me? What should I prepare to continue my education / career. To answer these questions, adolescents need to do career planning (Liza \& Rusandi, 2016; Nengsih, Firman, \& Iswari, 2015). This condition occurs because teenagers do not know whether the abilities (talents and interests, values in themselves, and skills) that are owned in accordance with the desired work/career environment. A study conducted by Zen (2012) of adolescents who are studying in high school level, found as many as $40 \%$ of adolescents do not recognize their own potential so confusion to choose and determine the career to be lived. Based on these results it can be interpreted the importance of knowing yourself in order to determine the next career choice. After knowing and understanding themselves, teenagers need to recognize the available work environment that will be the next career choice.

The various jobs available should be understood by adolescents as an alternative career choice that suits their personality. Various kinds of jobs available in the 4.0 era can be known by teens by searching search engines like 
Google. Teenagers can use the internet to explore various kinds of jobs/careers that exist today (Bowles \& Brindle, 2017). In fact the internet is used by teenagers to play online games, online shops, social media, and so on. This means that to explore the available work/career environment is not done by teenagers, even though this activity is part of the career planning process.

Teenagers who do not have the knowledge and insight about available career information tend to make them not successful through a career. As many as $40 \%$ of students drop out in the first year of college because they claim to choose the wrong department (Gautama, 2010). This condition is the result of not understanding information related to the requirements and skills that support someone succeeding in a particular department, so they cannot adjust to the department they are currently undergoing. Some of the results of these studies can be concluded that there are problems in the career field and this is the impact of low youth career planning.

The problem of adolescent career planning can be alleviated by the collaboration between parents and the government. Parents are the first and main source of education obtained by their children. When a child enters adolescence, parents should be involved in the career development of their children (Helwig \& Andrew, 2004). The form of involvement is discussing with their children about suitable career choices, guaranteeing children's education costs, and psychological support when the child is going / has gone through the desired career.

The government has the responsibility in providing education and counseling information and services for family growth and development (Irianto, Aimon, Nirwana, \& Prasetia, 2018). In order to improve the quality of adolescents a Generational Planning (Genre) program was formed. The program was developed in two forms, first through the Youth Counseling Information Center (PIK-R) and second by utilizing the Youth Family Development (BKR). The purpose of establishing BKR is so that families in this case parents who are members of BKR can know, understand, and be skilled in educating, including in planning their teenage children's careers (Alviani, 2017).

The right or not career choice also depends on the career exploration capacity possessed by parents and children (Mukhibat, 2016). Parents who understand the characteristics of their children can provide considerations regarding appropriate and available careers. Based on the research results of Code, Bernes, Gunn, \& Bardick (2006) which discusses the development of adolescent careers, shows the results that there is an influence of parental considerations on the career choices of adolescent children so that children become stable and confident to run the career.

The condition of BKR Parupuk Tabing Village career planning is still neglected. This is supported by interviews conducted on February 16, 2019 with three teenagers. The results of the interview are teenagers have doubts in choosing a career / high school, there are differences in the desires of children with parents related to their teenage career plans, so that children succumb and follow the wishes of parents, when children ask parents about careers that parents want to show their ignorance by responding " whatever".

Based on the problem that occurred, the researcher wanted to find out more about career planning in the BKR of Parupuk Tabing Village. After obtaining the research results from these variables, the researchers then developed a module based on the low career planning in each sub variable and per item. Modules can be used by BKR Counselors/Counselors in providing services to teenagers. The assumption is that adolescents can learn independently and gain new understanding by using module media.

This research will produce a product that is a career guidance module to improve BKR teen career planning by focusing on aspects of knowledge and understanding. The purpose of this study is to be able to produce material points that are appropriate in content and appearance, so that they can be used to improve teen career planning.

\section{METHOD}

This research uses the method of development (research and development) by applying the steps of the ADDIE model which includes Analyze, Desaign, Development, Implementation, and Evaluation (Branch, 2009). Development activities are carried out only in small groups / product usage tests by the BKR coach / counselor. The test subjects are experts in guidance and counseling to conduct a feasibility test on the contents and appearance of the module. The research objective is BKR Parupuk Tabing Village, Koto Tangah District, Padang City. Of the 30 existing families, 13 families with a total of 19 adolescents have cases related to adolescent career planning. Furthermore, researchers compile instruments in the form of questionnaires with a Likert Scale and analyze quantitatively the conditions of adolescent career planning. It is known that the instruments used in the test level of validity (item analysis) and reliability (Cronbach's Alpha) are declared valid per item and reliable (0.942).

The results of the analysis will be considered in determining the design of effective career guidance modules to improve teen career planning. After the material is designed, it is tested by the expert to be developed into a module.

\section{RESULTS AND DISCUSSIONS}

Everyone wants to be successful in life, including the career / work field. Achieving career success requires sound career planning. Research conducted on adolescent BKR Parupuk Tabing shows the low adolescent career planning, especially on aspects of attitude towards work. In some aspects there is a high career planning score, but the value is still not optimal and the amount is small. The total score shows that the level of adolescent career planning is in the moderate category with a range between 61.05 to 66.23 in four aspects. Meanwhile, one aspect is in the low category.

The conditions of youth career planning that are in the low category are very alarming. Based on the results of the percentages in Table 2, it can be seen that aspects of 
attitudes towards work are in the low category of 47.37 percent and none of them achieve a high score and are highest. Adolescent attitudes should be at work in the high category in order to plan a career so that success in a career. A person's career success is influenced by attitudes towards work which this aspect is part of career planning (Ellis, 2009).

Table 1 Overall Youth Career Planning Score

\begin{tabular}{|c|c|c|c|c|c|c|c|c|c|c|}
\hline Resp. & \multicolumn{2}{|c|}{ Self-understanding } & \multicolumn{2}{|c|}{$\begin{array}{c}\text { World } \\
\text { understanding }\end{array}$} & \multicolumn{2}{|c|}{ Attitude to Work } & \multicolumn{2}{|c|}{ Formulate } & \multicolumn{2}{|c|}{ Action Plan } \\
\hline 1 & 80,00 & High & 75,00 & High & 54,29 & Moderate & 66,15 & Moderate & 60,00 & Moderate \\
\hline 2 & 58,57 & Moderate & 55,00 & Moderate & 57,14 & Moderate & 66,15 & Moderate & 60,00 & Moderate \\
\hline 3 & 40,00 & Low & 62,50 & Moderate & 37,14 & Low & 61,54 & Moderate & 53,33 & Moderate \\
\hline 4 & 75,71 & High & 75,00 & High & 60,00 & Moderate & 75,38 & High & 66,67 & Moderate \\
\hline 5 & 65,71 & Moderate & 72,50 & High & 54,29 & Moderate & 63,08 & Moderate & 66,67 & Moderate \\
\hline 6 & 74,29 & High & 72,50 & High & 65,71 & Moderate & 69,23 & High & 66,67 & Moderate \\
\hline 7 & 62,86 & Moderate & 60,00 & Moderate & 51,43 & Low & 61,54 & Moderate & 66,67 & Moderate \\
\hline 8 & 65,71 & Moderate & 60,00 & Moderate & 57,14 & Moderate & 66,15 & Moderate & 66,67 & Moderate \\
\hline 9 & 54,29 & Moderate & 50,00 & Low & 42,86 & Low & 46,15 & Low & 40,00 & Low \\
\hline 10 & 71,43 & High & 65,00 & Moderate & 48,57 & Low & 55,38 & Moderate & 46,67 & Low \\
\hline 11 & 68,57 & High & 55,00 & Moderate & 45,71 & Low & 76,92 & High & 60,00 & Moderate \\
\hline 12 & 74,29 & High & 80,00 & High & 57,14 & Moderate & 72,31 & High & 66,67 & Moderate \\
\hline 13 & 60,00 & Moderate & 60,00 & Moderate & 42,86 & Low & 75,38 & High & 66,67 & Moderate \\
\hline 14 & 62,86 & Moderate & 75,00 & High & 51,43 & Low & 67,69 & Moderate & 53,33 & Moderate \\
\hline 15 & 60,00 & Moderate & 75,00 & High & 54,29 & Moderate & 70,77 & High & 66,67 & Moderate \\
\hline 16 & 68,57 & High & 70,00 & High & 51,43 & Low & 70,77 & High & 66,67 & Moderate \\
\hline 17 & 55,71 & Moderate & 65,00 & Moderate & 54,29 & Moderate & 66,15 & Moderate & 73,33 & High \\
\hline 18 & 47,14 & Low & 47,50 & Low & 40,00 & Low & 56,92 & Moderate & 53,33 & Moderate \\
\hline 19 & 67,14 & Moderate & 65,00 & Moderate & 54,29 & Moderate & 70,77 & High & 60,00 & Moderate \\
\hline Total & 63,83 & Moderate & 65,26 & Moderate & 51,58 & Low & 66,23 & Moderate & 61,05 & Moderate \\
\hline
\end{tabular}

Discussions conducted by teenagers with parents regarding career choices will shape the attitudes of their teenage career. In addition, these activities will strengthen the confidence of adolescents carrying out their careers. This is because the attitude that has been formed from discussions with parents will be raised in the form of behavior such as following an activity or skill that supports future career planning. Aspects of self-understanding, understanding of the world of work, formulating choices and planning actions are still dominated at a moderate level (Table 2). By paying attention to these conditions, we need a media that makes it easy for teens to do career planning. Modules are media that can be used by adolescents without dependence on material provided by BKR coaches or counselors (Musfirah, 2015).

Table 2. Adolescents in Career Planning

\begin{tabular}{|c|c|c|c|c|c|}
\hline Criteria & $\begin{array}{c}\text { Selft } \\
\text { Understandi } \\
\text { ng }\end{array}$ & $\begin{array}{c}\text { World } \\
\text { understandi } \\
\text { ng } \\
\text { work }\end{array}$ & $\begin{array}{c}\text { Attitu } \\
\text { de to } \\
\text { work }\end{array}$ & $\begin{array}{c}\text { Formula } \\
\text { te }\end{array}$ & $\begin{array}{c}\text { Actio } \\
\mathbf{n} \\
\text { Plan }\end{array}$ \\
\hline Highest & 0,00 & 0,00 & 0,00 & 0,00 & 0,00 \\
\hline High & 36,84 & 42,11 & 0,00 & 42,11 & 5,26 \\
\hline $\begin{array}{c}\text { Modera } \\
\text { te }\end{array}$ & 52,63 & 47,37 & 52,63 & 52,63 & 84,21 \\
\hline
\end{tabular}




\begin{tabular}{|c|c|c|c|c|c|}
\hline Low & 10,53 & 10,53 & 47,37 & 5,26 & 10,53 \\
\hline Lowest & 0,00 & 0,00 & 0,00 & 0,00 & 0,00 \\
\hline Total & 100 & 100 & 100 & 100 & 100 \\
\hline
\end{tabular}

Source: Processed from Primary Data, 2019

Table 3. Feasibility Test The Content and Display of the Career Guidance Module to Improve Career Planning

\begin{tabular}{|c|c|c|c|c|c|c|c|c|}
\hline \multirow[t]{2}{*}{ No } & \multirow{2}{*}{$\begin{array}{l}\text { Compo } \\
\text { nents }\end{array}$} & \multicolumn{3}{|c|}{ Expert Score } & \multirow{2}{*}{$\begin{array}{c}\text { Sco } \\
\text { re }\end{array}$} & \multirow{2}{*}{$\begin{array}{l}\sum_{\text {Ideal }} \\
\text { Score }\end{array}$} & \multirow[t]{2}{*}{$\%$} & \multirow{2}{*}{$\begin{array}{c}\text { Cate } \\
\text { gorie } \\
\text { s }\end{array}$} \\
\hline & & $\mathbf{A}$ & B & $\mathbf{C}$ & & & & \\
\hline 1 & Content & 120 & 118 & 118 & 356 & 405 & $\begin{array}{c}87 . \\
9\end{array}$ & VD \\
\hline 2 & Display & 115 & 112 & 114 & 341 & 360 & $\begin{array}{c}94 . \\
7\end{array}$ & VD \\
\hline & Total & 270 & 264 & 269 & 804 & 870 & $\begin{array}{c}91 . \\
3\end{array}$ & VD \\
\hline
\end{tabular}

Information

: VD (Very Decent)

Source

: Processed from Primary Data, 2019

Based on the data elaboration in Table 3, it can be seen that the whole career guidance module to improve career planning is developed in terms of content and appearance All aspects of career planning that include selfunderstanding, environmental understanding, attitudes toward work, formulating choices, and action plans can be used as a foundation for the development of modules that will be used in the BKR program to improve teen career planning. After conducting the content and appearance feasibility test, the researchers further refined the module based on suggestions from the supervisor and experts. Next, the researcher applies a career guidance module to BKR teens who aims to see the effectiveness of the module.

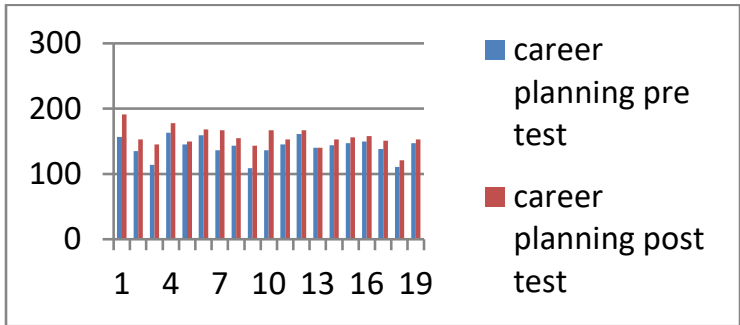

Chart 1 Career Planning (Pretest-Postest)

Based on the graph, it can be seen an increase in BKR teen career planning scores after the implementation of career guidance modules. Implementation of modules that contain theories of effective career guidance for adolescents to know and understand and apply their knowledge relating to career planning (Sukardi, 2010). means that the module can be used in order to improve BKR's teen career planning. This is also proved by the nonparametric Wilcoxon test (SPSS 20 version) results with the acquisition of asymp.sig value of 0,000 and less than 0.05 .

\section{CONCLUSIONS}

Based on the discussion and analysis of this data, it can be concluded that teen career planning before the module is implemented has not yet reached optimal results. After applying the module to adolescent BKR there is an increase in adolescent career planning. Then it can be concluded that the career guidance module developed is effective to improve teen career planning.

\section{ACKNOWLEDGMENTS}

The author appreciates Prof. Dr. A. Muri Yusuf, M. Pd., and Prof. Dr. Agus Irianto as a supervisor who has guided the authors so that the objectives of this study can be achieved. Next, thank you to Dr. Alizamar, M. Pd., Kons., And Dr. Afdal, M. Pd., Kons as a contributor who has provided criticism and suggestions for the impact of this research. Besides that, thank you to the BKR Parupuk Tabing teenagers who participated in this study. Both parents are the author Zainal and Rismayarni who have provided moral and material support, so that this research can be completed.

\section{REFERENCES}

[1] Alviani, A. (2017). Implementasi Program Bina Keluarga Remaja Oleh Badan Keluarga Berencana. Administrasi Negara, 5(3), 6502-6514.

[2] Atmaja, T. T. (2014). Upaya Meningkatkan Perencanaan Karir Siswa Melalui Bimbingan Karir dengan Penggunaan Media Modul. 3(2), 58-68.

[3] Bowles, T. V., \& Brindle, K. A. (2017). If ego identity is the envelope then adaptive change is the note to self: scaffolding the career choices of adolescents. International Journal for Educational and Vocational Guidance, 17(1), 5-18. https://doi.org/10.1007/s10775-016-9333-y

[4] Branch, R. M. (2009). Intructional Design: The ADDIE Aproach. New York: Springer Science and Business Media, LCC.

[5] Code, M. N., Bernes, K. B., Gunn, T. M., \& Bardick, A. D. (2006). Adolescents' Perceptions of Career Concern: Student Discouragement in Career Development. Canadian Journal of Counselling and Psychotherapy, 40(3), 160-174.

[6] Ellis, R. (2009). Career planning and development. California: The McGraw-Hill Companies.

[7] Gautama, B. S. (2010). DO akibat salah jurusan. Kompas.

[8] Helwig, \& Andrew, A. (2004). A ten-year longitudinal study of the career development of students: summary findings. Journal of Counseling 
\& Development, 82(1), 49-57.

[9] Irianto, A., Aimon, H., Nirwana, H., \& Prasetia, A. T. (2018). Populasi Komunikasi Interpersonal antara Orang Tua dan Anak Remaja serta Identitas Diri Remaja: Studi di Bina Keluarga Remaja Parupuk Tabing , Interpersonal Communication between Parents and Adolescents and Identity of Yourself: Study at Development Cad. Populasi, 26(1), 16-25.

[10] Istriyanti, N. L. A., \& Simarmata, N. (2014). Hubungan Antara Regulasi Diri dan Perencanaan Karir pada Remaja Putri Bali. Jurnal Psikologi Udaya, 1(2), 301-310.

[11]Liza, L. O., \& Rusandi, M. A. (2016). Pengaruh Layanan Informasi Tentang Studi Lanjut Terhadap Perencanaan Karir Siswa Kelas XI IPA SMA Negeri 1 Pekanbaru Tahun. Jurnal Bimbingan Konseling Indonesia, 1(1), 1-4.

[12] Michael, B., Minakshi, L., Sacip, T., \& Kelly Unger, H. (2016). Career Planning with Careerforward: Exploring Student Perceptions and Experiences in an Online Career Preparation Course. I-Manager's Journal on School Educational Technology, 11(3), 1. https://doi.org/10.26634/jsch.11.3.4785

[13] Mukhibat. (2016). Dukungan Keluarga, Peran Keputusan Karir, dan Career Indecision Siswa Sekolah Madiun. Palastren, 9(2), 279-304.

[14] Nengsih, Firman, \& Iswari, M. (2015). Pengaruh Layanan Bimbingan Kelompok Terhadap Perencanaan Arah Karier Siswa SMA Pembangunan Laboratorium Universitas Negeri Padang. 4(3), 136-146.

[15] Priyatno, T. (2016). Upaya Meningkatkan Pemahaman Eksplorasi Karir Melalui Layanan Bimbingan Kelompok dengan Teknik Diskusi Kelompok. Psikopedagogia, 5(1), 49-56.

[16] Sarwono. (2011). Psikologi Remaja. Jakarta: Raja Grafindo Persada.

[17] Sukardi, D. K. (2010). Bimbingan dan konseling di sekolah. Jakarta: Rineka Cipta.

[18]Zen, M. (2012). Faktor-Faktor Dominan Yang Berpengaruh Dalam Perencanaan Arah Karir. Program Studi Doktor Ilmu Pendidikan Universitas Negeri Padang, Padang. 